\title{
Management of lenticule detachment and epithelial downgrowth after Descemet stripping automated endothelial keratoplasty: a novel technique and brief literature review
}

\author{
Mohammad Soleimani ${ }^{1}$, Arash Alizadeh ${ }^{1}$, Maziyar Irannejad ${ }^{1}$, Mansoor Shahriari ${ }^{2}$ and Kasra Cheraqpour ${ }^{{ }^{*}(\text { (D) }}$
}

\begin{abstract}
Background: Epithelial downgrowth is a rare complication after Descemet stripping automated endothelial keratoplasty (DSAEK), which usually leads to poor visual outcome despite multiple available options of treatment.

Case presentation: A 50-year-old man underwent DSAEK procedure due to pseudophakic bullous keratopathy. Three months later, the patient presented with gradual visual loss; slit-lamp examination revealed detachment and folding of the DSAEK lenticule, which was confirmed by anterior segment optical coherence tomography. On confocal scanning, epithelial cell sheets were detected in the interface leading to the wrinkling of the donor tissue and donor detachment. Surgical debridement and transient fixating with straight 10-0 prolene needles were performed followed by air injection into the anterior chamber. The cornea turned clear in the one-year follow-up with uncorrected-visual acuity of 20/30 and best-corrected visual acuity of 20/25.

Conclusions: Early diagnosis and treatment of epithelial downgrowth may be associated with a good prognosis and prevent from more aggressive treatments such as repeat of grafting. In this case, mechanical debridement and transient fixation of lenticule by 10-0 prolene needles was performed to manage post-DSAEK epithelial downgrowth and lenticule detachment, which was successful without requiring of additional re-grafting. It seems this is a feasible technique with acceptable long-term outcomes.
\end{abstract}

Keywords: Epithelial downgrowth, Descemet stripping automated endothelial Keratoplasty, DSAEK, Surgical technique, Keratoplasty

\section{Background}

Penetrating injuries and intraocular surgeries may be complicated with invasion of the epithelium into the anterior chamber, which is called epithelial downgrowth (ED) or ingrowth [1]. Mechanism of ED is complex and multiple risk factors such as poor wound closure, numerous intraocular surgeries, wound fistula, and iris

\footnotetext{
*Correspondence: Cheraqpourk@gmail.com

${ }^{1}$ Eye Research Center, Farabi Eye Hospital, Tehran University of Medical Sciences, Tehran, Iran
}

Full list of author information is available at the end of the article or vitreous incarceration may have a role. ED manifests as milky sheets onto the posterior surface of the cornea with possible extension to the iris and anterior chamber angle [2]. Severe cases of this condition can lead to corneal endothelial failure, corectopia, and refractory glaucoma. The incidence of ED after cataract surgery and PK is about $0.1 \%$ and $0.25 \%$, respectively [1]. Management of this potentially vision-threatening entity is so challenging and the prognosis is guarded [3].

To the best of the author's knowledge and database search, few cases of ED after DSAEK have been reported in the last decades. We report a case of lenticule original author(s) and the source, provide a link to the Creative Commons licence, and indicate if changes were made. The images or other third party material in this article are included in the article's Creative Commons licence, unless indicated otherwise in a credit line to the material. If material is not included in the article's Creative Commons licence and your intended use is not permitted by statutory regulation or exceeds the permitted use, you will need to obtain permission directly from the copyright holder. To view a copy of this licence, visit http://creativecommons.org/licenses/by/4.0/. The Creative Commons Public Domain Dedication waiver (http://creativeco mmons.org/publicdomain/zero/1.0/) applies to the data made available in this article, unless otherwise stated in a credit line to the data. 
detachment and epithelial downgrowth after Descemet Stripping Automated Endothelial Keratoplasty, which managed through surgical debridement and transient fixating of lenticule by straight $10-0$ prolene needles not requiring a re-grafting.

\section{Case presentation}

A 50-year-old man presented with pseudophakic bullous keratopathy after cataract surgery. His visual acuity was counting fingers at $1 \mathrm{~m}$; the posterior capsule was intact with well-positioned intraocular lens (IOL) in the bag. The patient was scheduled for DSAEK surgery. In the DSAEK procedure, recipient corneal epithelium was removed and four venting incisions were made in the midperiphery of the cornea before Descemet stripping. The donor cornea was inserted using a Busin glide; after DSAEK lenticlue insertion, air injection was done up to the border of DSAEK lenticule. The surgical procedure resulted in a clear cornea. However, the patient presented with gradual visual loss three months later and the DSAEK lenticule was detached, non-mobile and folded confirmed by anterior segment optical coherence tomography (ASOCT) (CASIA SS-1000, TOMEY, Nagoya, Japan) (Fig. 1a, b). On confocal scanning microscopy (Heidelberg Retina Tomograph 3 with the Rostock Cornea Module, Heidelberg Engineering GmbH, Dossenheim, Germany), epithelial cell sheets were detected in the interface leading to the wrinkling of the donor tissue and detachment (Fig. 1c).

After general anesthesia, proper prepping and draping was done followed by placement of eyelid speculum and irrigation of ocular surface by povidone-iodine. In the primary maneuvers refractory nature of the detached lenticule to repositioning was noted and despite multiple attempts for re-surfacing and attachment of lenticule, shrinkage was happened. We thought that entered epithelial cells from venting incisions were culprit for this event. So, from the venting incision, epithelial cell sheets of the interface, which were diagnosed on confocal scanning and AS-OCT were carefully debrided and scraped using a secondary instrument and double cannula. After repeated irrigation and aspiration, epithelial strands were removed as much as possible. However, possibility of remaining some epithelial cells is still there. Then, we used several straight $10-0$ prolene needles for transient fixation of lenticule followed by full air injection (Fig. 2a, b). The needles were removed after five minutes and the air was deflated up to the lenticule border. These actions led to unfolded lenticule. The cornea turned clear in the one-year follow-up, with uncorrected-visual acuity of $20 / 30$ and best-corrected visual acuity of 20/25 (Fig. 3a, b) (Video 1). Also, preoperative and postoperative (1st year follow-up visit) CCT were $928 \mu \mathrm{m}$ and $598 \mu \mathrm{m}$, respectively.

\section{Discussion and conclusions}

Epithelial downgrowth is an uncommon condition. It may lead to devastating outcomes and catastrophic complications. Various intraocular surgeries such as cataract surgery, penetrating keratoplasty (PK), glaucoma filtering surgery, Descemet membrane endothelial keratoplasty (DMEK), and DSAEK may be complicated with ED [1]. It seems that outcomes of ED after DSAEK are probably better than non-DSAEK cases [4].

Previous studies have been shown that different risk factors such as several intraocular operations, poor wound closure, iris or vitreous incarceration, longstanding inflammation, corneal vascularization, and low intraocular pressure (IOP) may prone the eye to ED [1]. Moreover, the presence of intact Descemet membrane

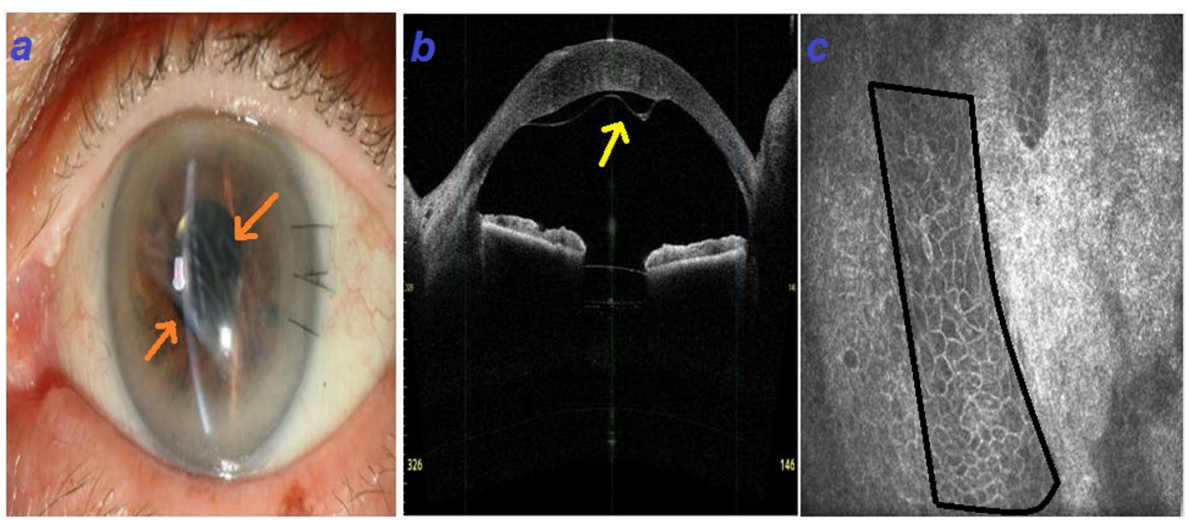

Fig. 1 Note to the white sheets on the endothelial surface representing lenticule detachment and epithelial downgrowth (orange arrows) (a) Anterior segment optical coherence tomography shows retraction and folding of the graft (yellow arrow) (b), Confocal scanning documented sheets of epithelial cells trapped in the stroma (marked area in black borders) (c) 

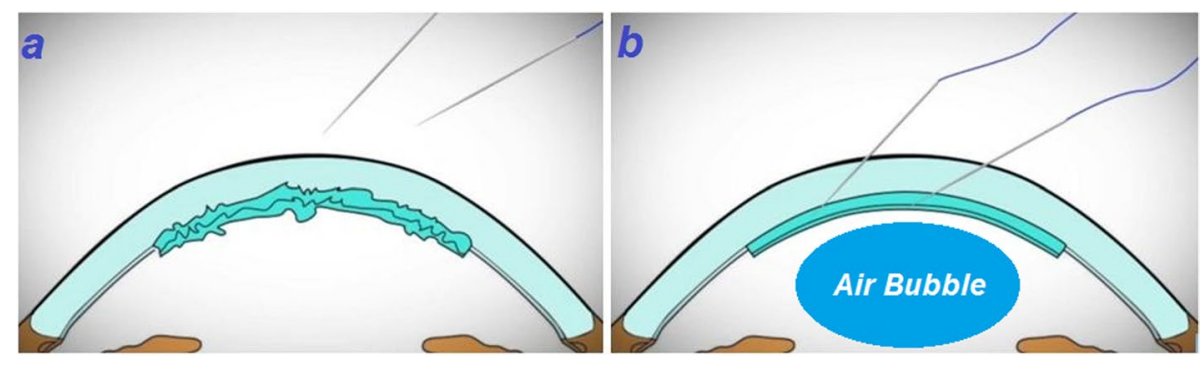

Fig. 2 Wrinkling of the donor tissue and donor detachment at the presentation (a). Using several 10-0 prolene needles for transient fixation of lenticule (b)
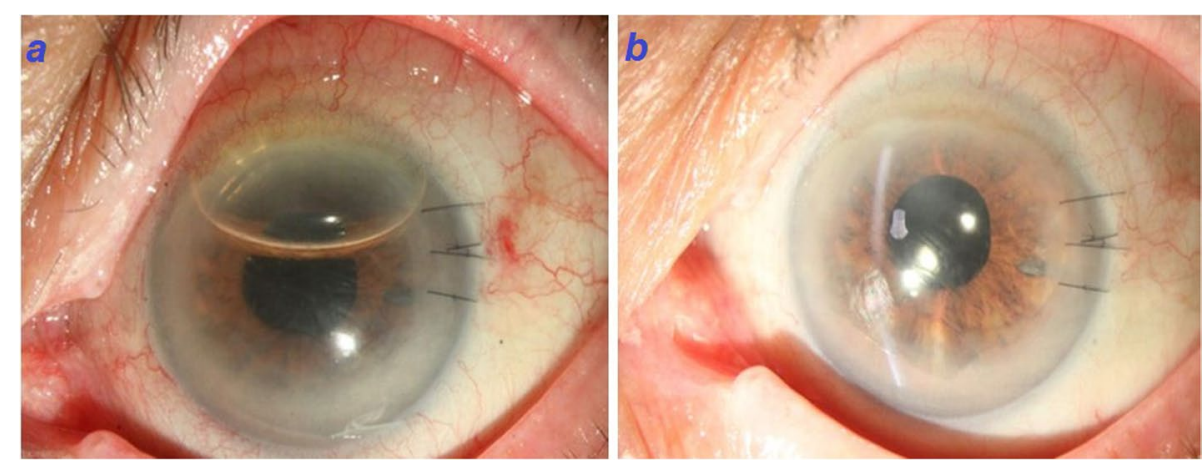

Fig. 3 First day follow-up visit after surgical debridement and air injection (a). Second follow-up visit after surgical procedure which shows a clear graft after resolution of epithelial downgrowth (b)

and endothelium is critical to block migration of epithelium into the anterior chamber, which can be lost due to DSAEK procedure. In other words, probable graft detachment may make a scaffold for the invasion of epithelial cells [5]. Risk factors of our patient were epithelial debridement during the procedure, large venting incision, use of 4 venting incisions, and also prolonged usage of contact lens which could transmit epithelial cells into the interface space to form a nest for subsequent retraction and donor tissue detachment.

Subtypes of ED include epithelial sheets, pearls, and cysts. Sheet type is the most common type of ED as occurred in our patient. Also, this type is the most destructive type, which may cause vision loss through glaucoma and corneal endothelial failure [1]. One study has been hypothesized that dragging of epithelial cells into the anterior chamber, decentered trephination of the graft, and implantation of epithelial cells from full-thickness corneal incision may play a role in pathophysiology of ED after DSAEK [1]. Epithelial cells may originate from either recipient or donor tissues [6]. In our case, several sources may be associated with the beginning location of epithelial downgrowth including the primary wound, paracentesis incisions and venting incisions.
We had been used from 4 venting incisions during surgery including: supratemporal, supranasal, infratemporal, and infranasal. Figure $1 \mathrm{a}$ is showing the epithelial sheets which are arranged from supranasal to infratemporal compatible with location of our venting incisions. Hence, it seems inculpating venting incision for source of downgrowth is not irrational. However, patient's corneal arcus has masked the changes of peripheral cornea in the images.

These patients usually turn symptomatic with decreased vision or pain. Non-specific features such as a hazy cornea, inflammation, and high IOP may make the diagnosis difficult. So, clinical suspicious can be helpful in these situations, especially in cases with history of previous ocular surgery. ED must be differentiated from iridocorneal endothelial (ICE) syndrome and metastatic carcinoma [7].

The gold standard method of the diagnosis is a histological assessment, which can also differentiate between the corneal or conjunctival origin of ED through the presence of goblet cells in cases with conjunctival source. Also, argon laser photocoagulation has a diagnostic value, which shows whitening of burn spots on invaded iris surface whereas healthy areas appear dark. Other 
noninvasive diagnostic modalities include ASOCT, confocal scanning, and specular microscopy [2].

Although there are some reports of spontaneous resolution of ED, various treatment options including surgical removal, cryotherapy, wide excision with adjunctive argon laser ablation, re-grafting through PK, DMEK, or DSAEK, and injection of antimetabolites like 5-FU into the anterior chamber are available. However, the failure rate of treatment is remarkable. It could be mentioned use of 5-FU was not successful in some cases [2]. Information on some of recent reports of ED after DSAEK (with available full text which managed surgically) including the elapsed time after procedure, the type of treatment, and visual outcomes are listed in Table 1.

The unique aspect of our report is management of epithelial downgrowth without requirement to re-grafting. Unlike previous reports of epithelial downgrowth after DSAEK which led to re-grafting (re-DSAEK or PK) after a short duration despite primary management with debridement or using 5-FU, our patient is currently stable through our novel technique without re-grafting (one-year follow-up, with uncorrected-visual acuity of $20 / 30$ and best-corrected visual acuity of 20/25). It should be mentioned that the presence of epithelial sheets and diagnosis of ED was made using confocal scanning since unlike the typical cases of epithelial downgrowth, epithelial sheets were so fine in our complicated case leading to poor visibility through surgical microscope. It's of note access and cleaning of epithelial sheets was done from venting incisions and interface scraping (but not excision) was tried to decrease the epithelial downgroth as less as possible. The authors have no claim regarding complete removal of epithelial sheets since this is not rationally possible and we think the reason of refractory nature of lenticule to repositioning is presence of remnant epithelial sheets. In this condition use of $10-0$ prolene needles beside air injection was helpful in stretching of lenticule resulting in attachment. The concern of further endothelial damage by penetration of lenticule is logically right but it should be mentioned the needles have very tiny

Table 1 Information of some of recent reports of epithelial downgrowth after DSAEK

\begin{tabular}{|c|c|c|c|c|c|c|c|}
\hline No. & Authors & $\begin{array}{l}\text { Elapsed time } \\
\text { after DSAEK }\end{array}$ & Risk factors & $\begin{array}{l}\text { Method of } \\
\text { diagnosis }\end{array}$ & Type of treatment & Using of 5-FU & Visual outcome \\
\hline 1 & Gorovoy et al. [6] & 4 years & $\begin{array}{l}\text { Decentered trephina- } \\
\text { tion }\end{array}$ & $\begin{array}{l}\text { Histopathological } \\
\text { evaluation }\end{array}$ & Repeat of DSAEK & No & $\begin{array}{l}\text { Initial BCVA: 20/30 } \\
\text { Final BCVA: } 20 / 30\end{array}$ \\
\hline \multirow[t]{3}{*}{2} & Itty et al. [4] & 7 months & Eccentric trephination & $\begin{array}{l}\text { Histopathological } \\
\text { examination }\end{array}$ & $\begin{array}{l}\text { Ablation with diode } \\
\text { laser which was not } \\
\text { successful and lead } \\
\text { to more surgeries } \\
\text { including PK. }\end{array}$ & Yes & $\begin{array}{l}\text { Initial BCVA: Not } \\
\text { mentioned } \\
\text { Final pinhole vision: } \\
20 / 200\end{array}$ \\
\hline & & 32 months & Unknown & $\begin{array}{l}\text { Histopathological } \\
\text { examination }\end{array}$ & $\begin{array}{l}\text { Argon laser ablation, } \\
\text { surgical membranec- } \\
\text { tomy with } \\
\text { repeat of DSAEK }\end{array}$ & Yes & $\begin{array}{l}\text { Initial BCVA: Not } \\
\text { mentioned } \\
\text { Final BCVA: 20/60 }\end{array}$ \\
\hline & & 32 months & $\begin{array}{l}\text { Several intraocular } \\
\text { surgeries }\end{array}$ & $\begin{array}{l}\text { Histopathological } \\
\text { examination }\end{array}$ & $\begin{array}{l}\text { Diode laser } \\
\text { Ablation, repeat of } \\
\text { DSAEK }\end{array}$ & Yes & $\begin{array}{l}\text { Initial BCVA: Not } \\
\text { mentioned } \\
\text { Final BCVA: Not } \\
\text { mentioned }\end{array}$ \\
\hline 3 & Phillips et al. [8] & 6 months & $\begin{array}{l}\text { Multiple surgeries, } \\
\text { presence of vitreous } \\
\text { within the surgical } \\
\text { wound }\end{array}$ & $\begin{array}{l}\text { Histopathological } \\
\text { examination }\end{array}$ & Repeat of DSAEK & No & $\begin{array}{l}\text { Initial BCVA: 20/400 } \\
\text { Final BCVA: } 20 / 80\end{array}$ \\
\hline \multirow[t]{2}{*}{4} & Prasher et al. [5] & 15 months & $\begin{array}{l}\text { significant postop- } \\
\text { erative inflammation, } \\
\text { multiple surgeries, } \\
\text { detached graft }\end{array}$ & $\begin{array}{l}\text { Histopathological } \\
\text { examination, ASOCT }\end{array}$ & PK & No & $\begin{array}{l}\text { Initial BCVA: 20/200 } \\
\text { Final BCVA: Not } \\
\text { mentioned }\end{array}$ \\
\hline & & 14 months & $\begin{array}{l}\text { significant postop- } \\
\text { erative inflammation, } \\
\text { multiple surgeries }\end{array}$ & $\begin{array}{l}\text { Histopathological } \\
\text { examination, ASOCT }\end{array}$ & Repeat of DSAEK & No & $\begin{array}{l}\text { Initial BCVA: 20/400 } \\
\text { Final BCVA: Not } \\
\text { mentioned }\end{array}$ \\
\hline 5 & Wong et al. [9] & 7 months & $\begin{array}{l}\text { Multiple intraocular } \\
\text { surgeries }\end{array}$ & $\begin{array}{l}\text { Argon laser photoco- } \\
\text { agulation, histopatho- } \\
\text { logical examination }\end{array}$ & Repeat DSAEK & Yes & $\begin{array}{l}\text { Initial BCVA: 20/100 } \\
\text { Final BCVA: } 20 / 30\end{array}$ \\
\hline 6 & Walker et al. [10] & 3 months & $\begin{array}{l}\text { Multiple intraocular } \\
\text { surgeries, prolonged } \\
\text { inflammation }\end{array}$ & $\begin{array}{l}\text { In Vivo Confo- } \\
\text { cal Microscopy, } \\
\text { histopathological } \\
\text { examination }\end{array}$ & $\begin{array}{l}\text { PK with adjunctive } \\
\text { cryotherapy }\end{array}$ & No & $\begin{array}{l}\text { Initial pinhole vision: } \\
\text { 20/80 } \\
\text { Final BCVA: Not } \\
\text { mentioned }\end{array}$ \\
\hline
\end{tabular}


cross section and we believe endothelial damage following possible penetration was not significant. Our witness for this claim is comparison between preoperative and postoperative endothelial cell count (at 1st year of followup) in which 2327 cells $/ \mathrm{mm}^{2}$ was changed to 2109 cells/ $\mathrm{mm}^{2}$.

At the time being, no study is available on direct comparison between outcomes of graft exchanging and debridement. Although this condition is so rare, future studies may be helpful to address the preferred option. Nevertheless, we deeply believe that giving a chance to the patients for prevention from re-grafting and its subsequent issues is a logical approach.

In conclusion, early diagnosis and treatment of epithelial downgrowth may be associated with a good prognosis and prevent from more aggressive treatments such as repeat of grafting. In this case, mechanical debridement and transient fixation of lenticule by $10-0$ prolene needles was performed to manage post-DSAEK epithelial downgrowth and lenticule detachment, which was successful without requiring of additional re-grafting. It seems this is a feasible technique with acceptable longterm outcomes.

\section{Abbreviations}

ED: epithelial downgrowth; PK: penetrating keratoplasty; DSAEK: Descemet stripping automated endothelial keratoplasty; IOL: intraocular lens; ASOCT: anterior segment optical coherence tomography; DMEK: Descemet membrane endothelial keratoplasty; IOP: intraocular pressure; ICE: iridocorneal endothelial syndrome.

\section{Supplementary Information}

The online version contains supplementary material available at https://doi. org/10.1186/s12886-022-02264-7.

Additional file 1: Video 1. Shows the used surgical technique.

\section{Acknowledgements}

N/A

\section{Authors' contributions}

MS1 visited the patient, performed treatment and collected the patient information. KC wrote the manuscript. MS1, AA, MI, and MS2 performed critical revisions on manuscript. All authors read and approved final manuscript.

\section{Funding}

N/A

\section{Availability of data and materials}

The data is available from the corresponding author on reasonable request.

\section{Declarations}

\section{Ethics approval and consent to participate}

This study adhered to the tenets of the Declaration of Helsinki. Ethics committee approval was not required for this case report.

\section{Consent for publication}

We obtained written consent to publish from the patient for publication of this case report.

\section{Competing interests}

The authors declare no potential conflicts of interest.

\section{Author details}

${ }^{1}$ Eye Research Center, Farabi Eye Hospital, Tehran University of Medical Sciences, Tehran, Iran. ${ }^{2}$ Imam Hossein Medical Center, Shahid Beheshti University of Medical Sciences, Tehran, Iran.

Received: 19 July 2021 Accepted: 19 January 2022

Published online: 29 January 2022

\section{References}

1. Le VNH, Wabnig F, Bachmann B, Cursiefen C. Epithelial downgrowth after Descemet membrane endothelial keratoplasty. Eur J Ophthalmol. 2021;31(2):NP27-32.

2. Vargas LG, Vroman DT, Solomon KD, Holzer MP, Escobar-Gomez M, Schmidbauer JM, et al. Epithelial downgrowth after clear cornea phacoemulsification: report of two cases and review of the literature. Ophthalmology. 2002;109(12):2331-5.

3. Kim YS, Jin S-Y, Chung JK. Descemet membrane endothelial keratoplasty for epithelial downgrowth after clear corneal cataract surgery. Eye \& contact lens. 2018;44:S326-9.

4. Itty S, Proia AD, DelMonte DW, Santaella RM, Carlson A, Allingham RR, Clinical course and origin of epithelium in cases of epithelial downgrowth after Descemet stripping automated endothelial keratoplasty. Cornea. 2014;33(11):1140-4.

5. Prasher P, Muftuoglu O, Hsiao M, Bowman RW, Hogan RN, Mootha W. Epithelial downgrowth after descemet stripping automated endothelial keratoplasty. Cornea. 2009;28(6):708-11.

6. Gorovoy MS, Ratanasit A. Epithelial downgrowth after Descemet stripping automated endothelial keratoplasty. Cornea. 2010;29(10):1192-4.

7. Patel HR, Margo CE: Epithelial downgrowth. Report of 2 cases diagnosed by ocular biopsy. Ann Diagn Pathol. 2017;26:60-3.

8. Phillips PM, Terry MA, Kaufman SC, Chen ES. Epithelial downgrowth after Descemet-stripping automated endothelial keratoplasty. J Cataract Refract Surg. 2009:35(1):193-6.

9. Wong RK, Greene DP, Shield DR, Eberhart CG, Huang JJ, Shayegani A. 5-fluorouracil for epithelial downgrowth after Descemet stripping automated endothelial keratoplasty. Cornea. 2013;32(12):1610-2.

10. Walker BM, Hindman HB, Ebrahimi KB, Green WR, Eberhart CG, Garcia I, et al. Epithelial downgrowth following Descemet's-stripping automated endothelial keratoplasty. Arch Ophthalmol. 2008;126(2):278-80.

\section{Publisher's Note}

Springer Nature remains neutral with regard to jurisdictional claims in published maps and institutional affiliations.

Ready to submit your research? Choose BMC and benefit from:

- fast, convenient online submission

- thorough peer review by experienced researchers in your field

- rapid publication on acceptance

- support for research data, including large and complex data types

- gold Open Access which fosters wider collaboration and increased citations

- maximum visibility for your research: over $100 \mathrm{M}$ website views per year

At BMC, research is always in progress.

Learn more biomedcentral.com/submissions 